\title{
Cytoplasmic Nucleophosmin Expression
}

National Cancer Institute

\section{Source}

National Cancer Institute. Cytoplasmic Nucleophosmin Expression. NCI Thesaurus. Code C117284.

A variant form of nucleophosmin with cytoplasmic expression. These variants have either a 4-base or 9-base insertion in exon 12 of the NPM1 gene. Acute myelogenous leukemia with normal cytogenetics and cytoplasmic nucleophosmin (NPMC+ AML) constitutes about one third of the cases of primary AML in adults. 